УДК $340+341.01$

DOI: https:// doi.org/10.47567/ bomivit.1-3.2020.07

М. О. Баймуратов, доктор юридичних наук, професор головний науковий консультант Інституту законодавства Верховної Ради України Заслужений діяч науки і техніки baymuratov@ukr.net

ORCID: https:/ / orcid.org/0000-0002-4131-1070

В. П. Ожерельєв, аспірант кафедри кафедри філософії Національного університету «Одеська юридична академія» halsband.v@gmail.com ORCID: https:/ / orcid.org/0000-0001-9752-0392

\title{
ЮРИДИЧНА НООСФЕРОЛОГІЯ ЯК НАУКОВА І НАВЧАЛЬНА ДИСЦИПЛІНА: ОБ'СКТ, ПРЕДМЕТ І МЕТОДИ ДОСЛІДЖЕНЬ
}

M. O. Baimuratov, Doctor of Law, Professor, chief scientific consultant Legislation Institute of

The Verkhovna Rada of Ukraine Honored Worker of Science and Technology baymuratov@ukr.net ORCID: https:/ / orcid.org/0000-0002-4131-1070

V.P. Ozhereliev, Post-graduate student of the Department of Philosophy National University "Odessa Law Academy" halsband.v@gmail.com ORCID: https://orcid.org/0000-0001-9752-0392

\section{LEGAL NOOSPHEROLOGY AS A SCIENTIFIC AND EDUCATIONAL DISCIPLINE: OBJECT, SUBJECT AND METHODS OF RESEARCH}

Стаття присвячена визначенню об'єкта, предмета і методів досліджень юридичної ноосферології як наукової і навчальної дисципліни. Доводиться, що юридична ноосферологія $€$ новою перспективною науковою $\mathrm{i}$ навчальною 
дисципліною, в рамках якої на основі міждисциплінарного підходу можливо досліджувати широкий спектр актуальних міжгалузевих цивілізаційних проблем комплексними методами - правознавства та ноосферології. Такий міждисциплінарний - юридико-ноосферний підхід, що розроблений авторами статті, - призначений для моніторингу процесу правової глобалізації, розробки системи ноосферного права і методів МП-прогнозування, - заснований на наукових уявленнях про природну єдність і безперервність простору цивілізаційно-правових подій. Своєю чергою, це дає підставу застосувати в юридико-ноосферних дослідженнях наукові методи теорії подібності, загальної топології і теорії ігор та ін., відповідно до математичних понять про «цілісність» $\mathrm{i}$ «нерозривність» досліджуваного глобального об'єкта. Здійснення досліджень на платформі юридичної ноосферології з використанням, топологічної інформаційно-правової Моделі ноосфери, що розроблена авторами, дозволяє вивчати виникнення i розвиток цілісного юридико-ноосферного природного феномена в єдиному просторовому континуумі в реальному часі в науковому експерименті. Такі можливості особливо важливі для пізнання законів сталого розвитку світової цивілізації в їх екологічному та правовому додатку і глобальному прояві - тобто в телеологічно обгрунтованої діяльності 3 МП-прогнозування. Це вказує на найважливішу роль юридичної ноосферології як наукової і навчальної дисципліни, яку вона здатна грати, - причому, не тільки в розробці системи ноосферного права, в розвитку всієї системи юридичних і геополітичних наук, а й розвитку різних напрямків досліджень в глобалістиці.

Ключові слова: глобалізація, правова глобалізація, глобалістика, юридична ноосферологія, об'єкт юридичної ноосферології, предмет юридичної ноосферології, методи юридичної ноосферології, юридико-ноосферний підхід, топологічна інформаційно-правова Модель ноосфери.

The article is devoted to the definition of the object, subject and research methods of legal noospherology as a scientific and educational discipline.

It is pointed out that the formation of "legal noospherology" as an interdisciplinary science is a natural result of the process of human cognition of the world around us. The initial accumulation of information and further differentiation of a single system of primary knowledge about the laws of nature and society, the allocation of independent disciplines and the subsequent need to solve intersectoral problems - inevitably lead to the formation of new interdisciplinary sciences. Examples that confirm this pattern are the scientific and educational disciplines "legal anthropology" and "legal sociology". They were created to solve current intersectoral problems based on the sciences of law, anthropology and sociology.

It is proved that legal noospherology is a new promising scientific and educational discipline, in which on the basis of an interdisciplinary approach it is possible to study a wide range of current intersectoral civilizational problems by complex methods jurisprudence and noospherology. This interdisciplinary - legal-noosphere approach, developed by the authors of the article - is designed to monitor the process of legal globalization, development of noosphere law and methods of MP-forecasting - based on scientific ideas about the natural unity and continuity of civilizational events. In turn, this gives grounds to apply in legal and noosphere research scientific methods of similarity theory, general topology and game theory, etc., in accordance with the mathematical 
concepts of "integrity" and "continuity" of the studied global object. Carrying out research on the platform of legal noospherology using the topological information-legal Model of the noosphere developed by the authors allows to study the origin and development of a holistic legal-noosphere natural phenomenon in a single spatial continuum in real time in a scientific experiment. Such opportunities are especially important for understanding the laws of sustainable development of world civilization in their ecological and legal application and global manifestation - that is, in teleologically sound activities of MPforecasting. This indicates the most important role of legal noospherology as a scientific and educational discipline that it is able to play - and not only in the development of noosphere law, in the development of the entire system of legal and geopolitical sciences, but also the development of various areas of research in globalism.

Key words: globalization, legal globalization, globalism, legal noospherology, object of legal noospherology, subject of legal noospherology, methods of legal noospherology, legal-noosphere approach, topological information-legal Model of the noosphere.

Постановка проблеми. Становлення «юридичної ноосферології», як міждисциплінарної науки, є закономірний результат процесу пізнання людиною навколишнього світу. Первісне накопичення інформації і подальша диференціація єдиної системи первинних знань про закони розвитку природи і суспільства, виділення самостійних дисциплін і подальша необхідність вирішення міжгалузевих завдань, - неминуче призводять до формування нових міждисциплінарних наук. Прикладами, які підтверджують цю закономірність, $\epsilon$ наукові та навчальні дисципліни «юридична антропологія» $\mathrm{i}$ «юридична соціологія». Вони були створені для вирішення актуальних міжгалузевих завдань на основі наук юридичного, антропологічного та соціологічного циклу.

У сучасному природничому дискурсі такі понятійні категорії, як «ноосфера», «антропосфера», або «соціосфера», прийнято вважати тотожними. Однак термін «ноосфера», як «сфера розуму», являє собою більш глибокий - природнофілософський зміст, ніж терміни «антропосфера» або «соціосфера». Треба відзначити, що простір «антропосфери», або «соціосфери», як сфери речовинної діяльності людини - складова частина ії наукової розумової, зокрема, правотворчої, а також і правозастосовної діяльності, в ноосфері в цілому. Отже, процес «поділу світу» в пізньому Середньовіччі, регіональна юридизація, що передувала йому, правова глобалізація ноосфери, що послідувала за нею і виникнення в планетарному масштабі системи міжнародного публічного права (далі - МПП), - є нерозривними 3 загальними цивілізаційно-правовими процесами в ноосфері. Тому, як найбільш наповнена смислова категорія, «ноосфера» спочатку вже містить в собі поняття про «антропосферу» і «соціосферу», системні правові явища і процеси в яких становлять предмет вивчення юридичної антропології та юридичної соціології.

I хоча юридична ноосферологія, здавалося б, здатна узагальнити у своєму широкому науковому контексті і юридичну антропологію, і юридичну соціологію, тим не менш, вона призначена для вирішення особливих питань - звідси вона має свої особливі цілі, завдання, об'єкт і предмет вивчення, методи досліджень. Однак це не виключає застосування в юридичній ноосферології, при вивченні юридикоцивілізаційних явищ і процесів, різних підходів і методів, які характерні для юридичної антропології та юридичної соціології. 
В даний час внаслідок появи і розвитку феноменології правової глобалізації, розширення масштабів застосування МПП в повсякденному житті світової спільноти держав та міжнародних організацій, конституційно-економічних і конвергентноправових перетворень, в системі суб'єктів МПП, особливо в їх нормотворчості спостерігаються ознаки процесу формування загальнопланетарної системи права ноосферного права. Це вказує на актуальність розвитку юридичної ноосферології як теоретичної платформи для дослідження інформаційно-правових цивілізаційних процесів і явищ в проекції на систему ноосфери, простір якої володіє топологічними властивостями.

Аналіз останніх досліджень і публікацій. Об'єктивно встановлено, що в світовій науковій періодиці відсутні роботи, де обговорювалося б питання про створення нового міждисциплінарного напряму досліджень в юридичних та природничих науках, яке автори називають «юридичною ноосферологією». Однак у вітчизняній, а також у російськомовній науковій літературі в цілому, є досить робіт, в яких розглядаються на рівні різних організаційних форм і аспектів питання про необхідність розробки і розвитку системи ноосферного права. Внаслідок аналізу існуючих на цю тему публікацій, в яких сама ноосфера також представляється в різних аспектах, - як суто філософських, футурологічних, так і релігійно-містичних, автори бачать необхідність у створенні наукової природно-правової основи для розробки системи ноосферного права. Такою теоретичною основою, яку в даний час активно розробляють автори, повинна стати нова наукова і навчальна правова дисципліна - «юридична ноосферологія».

Метою статті $є$ а) обгрунтування необхідності створення нової наукової i навчальної дисципліни - «юридичної ноосферології», в першу чергу, як теоретичної основи для розробки системи ноосферного права; б) визначення загальних цілей, завдань, об'єкта, предмета та методів досліджень «юридичної ноосферології», як наукової і навчальної дисципліни в системі правових наук.

Виклад основного матеріалу. Головною метою юридичної ноосферології $\epsilon$ вивчення процесу зародження, появи, формування, розвитку і подальшої організації моніторингу інформаційно-правової системи ноосфери, як геокосмічного екологоправового об'єкта, який володіє топологічними особливостями i наділений «природною двоконтурною оболонково-ядерною інформаційно-правовою структурою». Для досягнення поставленої мети, авторами раніше в порядку наукової дискусії було висловлено думку про необхідність створення єдиної аналітичної моделі МПП і ноосфери. Надалі це призвело авторів до усвідомлення і оцінки існування «природної інформаційно-правової структури ноосфери», як важливого наукового факту. Згодом, згідно 3 принципом подібності в будові природних систем, дану структуру автори відобразили через створену ними «топологічну двоконтурну оболонково-ядерну інформаційно-правову модель ноосфери» (далі - Модель). Використання даної Моделі, яка є методологічною основою юридичної ноосферології, в додатку до геополітики, глобалістики та інших галузей знань, дозволить, в процесі розширення області застосування Моделі, найбільш ефективно реалізувати науково-теоретичний, експериментальнодослідний і навчальний потенціал юридичної ноосферології.

Головним завданням юридичної ноосферології є розробка наукових основ системи ноосферного права, яка, згідно з природною системною ієрархією, являє собою метасистему, або глобальну надсистему права. Необхідно уточнити, що 
відповідно до юридико-типологічної класифікації, в правових науках відомо два типи права. Перший тип права - міжнародне право (далі - МП) - самостійна правова система, де основним предметом регулювання є відносини між державами, націями, міжнародними міжурядовими організаціями, а також державоподібними утвореннями. Незважаючи на певні відмінності між цими суб'єктами МП, можна цілком коректно кваліфікувати взаємини між ними, як міждержавні відносини. До другого типу права можна адресувати системи національного права (далі - НП), або ж внутрішньодержавного права, в сукупності основних (головних) суб'єктів МП. До цього типу належать близько 200 самостійних НП систем, основним предметом регулювання яких є, першою чергою, внутрішньодержавні суспільні відносини між суб'єктами НП.

Іншими словами, в термінах топології і понять про глобальний простір правових подій, можна сказати, що ноосферне право - це глобальна надсистема права, яка вкладена в глобальне топологічне інформаційно-правове різноманіття ноосфери. Отже, згідно з юридико-типологічною класифікацією понять і термінів теорії множин, ноосферне право, як надсистема, включає в себе: систему МП, як кінцеву безліч підсистем - галузей МП, а також систему НП, з кінцевою безліччю НП, як підсистем, в загальній системі НП. 3 даного положення витікає, що ноосферне право необхідно позиціонувати, як глобальну надсистему юридичних принципів і норм, що регулюють, відповідно до Моделі, міжсистемні правові відносини між суб'єктами НП щодо галузей, а також інститутів МП, - з метою забезпечення миру, міжнародної безпеки, побудови системи міжнародного, насамперед міждержавного, співробітництва і сталого розвитку світової цивілізації. Також не слід забувати, що розробка «системи» ноосферного права, повинна здійснюватися, насамперед, відповідно до екологічних і гуманітарних принципів з дотриманням правових норм. При цьому встановлення природно-правових закономірностей і моніторинг, так званого, «сталого», а по суті «необхідного і достатнього» - «можливого i допустимого» рівня і ступеня розвитку світової цивілізації в системі ноосфери, є пріоритетним напрямом досліджень юридичної ноосферології.

Все це вимагає створення особливої природно-правової науково-теоретичної бази відповідно до цілісного - топологічного інформаційно-правового підходу, який виражається у відображенні єдності і безперервності перетворення правової структури простору подій в світовому цивілізаційному континуумі. Дане завдання виникає в умовах перманентного «поділу світу», правової глобалізації, потреби в підтримці процесу «стійкого» розвитку світової цивілізаційної системи та вирішення різних екологічних і гуманітарних проблемних питань світової спільноти.

Отже, об'єктом вивчення юридичної ноосферології, як наукової і навчальної дисципліни, є глобальна правова система ноосфери, яка, згідно 3 дослідженнями авторів, має природну топологічну двоконтурну «оболонково-ядерну» інформаційно-правову структуру. С підстави стверджувати, що дана інформаційноправова структура утворилася внаслідок первинної регіональної юридизації і подальшої правової глобалізації цивілізаційного простору ноосфери під впливом антропогенних і соціогенних чинників. Необхідно зазначити, що простір ноосфери наповнений фізико-географічними, військово-стратегічними, екологоекономічними, соціально-культурними об'єктами, а також правовими об'єктами i суб'єктами глобального і локального системного рівнів. Всі вони беруть участь у правовій глобалізації, взаємодіють між собою, і тому здатні активно впливати на 
динаміку процесу сталого розвитку світової цивілізації в системі ноосфери. Більш того, вони самі, в залежності від свого системного рівня, неодмінно підпадають, в тій чи іншій мірі, під ії вплив. Дані аспекти досліджень можуть представляти особливий інтерес в додатку до моніторингу конституційно-економічної і конвергентноправової динаміки політичної структури держави Україна, яка виступає, як найбільша по території європейська держава, найважливішим геополітичним гравцем - суб'єктом міжнародних відносин в системі МПП.

Тому стає ясно, чому особливо важливим предметом вивчення юридичної ноосферологія $є$ інформаційно-правові властивості ноосфери, які в поєднанні з іï топологічними особливостями, згідно $з$ дослідженнями авторів, виключно активно впливають на стійкість розвитку світових цивілізаційних процесів в ноосфері.

Слід зазначити, що в основі явища регіональної юридизації, правової глобалізації, а також інформаційно-правової структуризації ноосфери, знаходиться природний процес експансії біологічного виду Homo sapiens в екологічному просторі нашої планети. В історичній географії цей процес відомий, як «епоха великих географічних відкриттів», яка почалася в пізньому Середньовіччі в кінці XV століття. Результатом цих географічних відкриттів став «поділ світу» і виникнення системи МП в планетарному масштабі.

Характерно, що особливо потужний вплив на інформаційно-правову систему ноосфери антропогенні та соціогенні фактори стали надавати під час історичного періоду, який триває останні 500 років. Він приурочений до початку «поділу світу» $\mathrm{i}$ триває по теперішній час. Вищевказані фактори у вигляді наукової розумової діяльності людини ініціювали початок «епохи великих географічних відкриттів», як нової особливо активної фази ноосферогенезу. Вони спричинили за собою «поділ світу» в формі реструктуризації геополітичного простору за формулою «від захоплення території - до ії узаконення» (через окулярну або ефективну окупацію 3 наступною легалізацією), виникнення світової колоніальної системи, а також подальшу повну юридизацію і початок правової глобалізації системи ноосфери. Всі ці процеси і призвели до утворення топологічної двоконтурної «оболонковоядерної» інформаційно-правової структури в системі ноосфери, юридикоцивілізаційні явища в якій складають предмет вивчення юридичної ноосферології. Дану подію слід вважати не тільки початком процесу «поділу світу» в глобальному масштабі, а й початком «нового осьового часу» (далі - «НОВ») в історії ноосферогенезу - початком нових еколого-економічних перетворень в цивілізаційно-правовому геополітичному просторі нашої планети в цілому.

Стає зрозумілим, що остаточна і повна юридизації глобального простору ноосфери здійснилася, в умовах процесу правової глобалізації та виникнення системи МПП при одночасному формуванні «глобальної топологічної двоконтурної оболонково-ядерної інформаційно-правової структури» в системі ноосфери. Згідно 3 дослідженнями авторів, головна природна функція цієї структури - це забезпечення процесу сталого розвитку світової цивілізаційної системи, що власне і $є$ одним з основних предметів дослідження юридичної ноосферології. Відповідно до предмету дослідження юридичної ноосферології, для вивчення процесу сталого розвитку світової цивілізації, який пов'язаний з повною юридизацією ноосфери, використовуються певні для даної правової дисципліни методи, що відповідають ії цілям і завданням. Для досягнення зазначених цілей та вирішення поставлених завдань, які пов'язані 3 прогнозуванням цивілізаційно-правових процесів, 
розробляються спеціальні математичні методи моделювання на основі принципів теорії подібності, загальної топології, теорії ігор та ін.

Основою для розвитку методів моделювання $є$ топологічна інформаційноправова Модель ноосфери, яка використовується для дослідження інформаційноправових процесів, що забезпечують сталий розвиток світової цивілізації в системі ноосфери. Необхідно нагадати, що конструкція даної Моделі відображає природну будову «топологічної двоконтурної оболонково-ядерної інформаційно-правової структури» сучасної ноосфери. Тому можна з упевненістю заявити, що збереження цієї структури ноосфери в стабільному стані і забезпечення процесу сталого розвитку світової цивілізації в системі ноосфери - це, по своїй суті, єдина гуманітарна проблема людства i головний напрямок наукових досліджень юридичної ноосферології.

Автор підручника «Юридична соціологія» Жан Карбонье вважає, що соціологи права подібно криміналістам, які розрізняють кримінальне право на загальну і особливу частину, повинні застосувати такий поділ і для юридичної соціології. 3 цією думкою згодні і автори даної статті, які мають намір реалізувати такий же принцип при розробці структури нової правової дисципліни - юридичної ноосферології.

У загальну частину юридичної ноосферології, яка фактично буде введенням в особливу частину, увійдуть теоретичні розробки - історико-географічні та природно-правові відомості про походження і розвиток інформаційно-правової структури ноосфери і системи МПП. Завдання особливої частини полягає в перенесенні цих понять в різні галузі права, першою чергою, до галузевих підрозділів системи МПП, а потім і в систему національних підсистем - галузей НП держав, як основних (головних) суб'єктів МПП.

У загальній частині будуть розглянуті закони сталого розвитку світової цивілізації, викладена функціональна роль глобальної інформаційно-правової структури ноосфери, згідно Моделі, i такі, що є співвідносні з формуванням системи МПП в планетарному масштабі. У ній також буде відображена роль фактору «НОВ», як початку процесу «поділу світу», або ж початку інформаційно-правової глобалізації та структуризації ноосфери. Також буде дана оцінка його впливу на розвиток інформаційно-правової структури ноосфери з позиції теорії і історії права і правової компаративістики: до «НОВ» (завершення регіональної юридизації) і після «НОВ» (початок правової глобалізації), або іншими словами, - до формування та становлення «глобальної топологічної двоконтурної оболонково-ядерної інформаційно-правової структури ноосфери» і після її формування.

В особливій частині будуть наведені глобальні та локальні геополітичні чинники правового середовища, що порушують сталий розвиток цивілізації, вказані ix можливі гуманітарні наслідки, а також поіменовані правові інструменти, що можуть бути використаними для усунення шкідливих факторів середовища в проекції на існуючі системи, інститути та галузі МП і НП. Також будуть приведені дані про взаємодію інформаційно-правової структури ноосфери 3 особистістю людини, іï поведінки в умовах даної структури, як соціальної істоти, в правових проявах, вимірах, характеристиках і контекстуалізації. Ці дослідження, в першу чергу, можуть торкнутися історичних особистостей: В. Черчилля, Т. Рузвельта, А. Гітлера, Й. Сталіна, Мао-Цзедуна, Махатми Ганді та ін., а також сучасних лідерів і представників етнічних, соціальних і релігійних меншин. Саме в особливій частині 
предмет дослідження юридичної ноосферології може глибоко перетинатися 3 предметом дослідження юридичної антропології та юридичної соціології.

I все ж, головним об'єктом дослідження для юридичної ноосферології є i залишається глобальна інформаційно-правова структура ноосфери, як юридиконоосферний об'єкт - гарант сталого розвитку світової цивілізації, що буде закріплено в загальній частині цієї правової дисципліни. Принципи будови та правові функції цієї структури ноосфери мають концептуальне значення для розробки системи ноосферного права. При іï створенні в процесі попередніх досліджень буде здійснено пошук можливих, допустимих і достатніх рішень гуманітарних проблем, що є співвідносними з особливостями кожної соціальної групи і окремої людської особистості.

Висновки. Юридична ноосферологія є новою перспективною науковою i навчальною дисципліною, в рамках якої на основі міждисциплінарного підходу можна досліджувати широкий спектр актуальних міжгалузевих цивілізаційних проблем комплексними методами - правознавства та ноосферології. Такий міждисциплінарний - юридико-ноосферний підхід, що розроблений авторами статті, - призначений для моніторингу процесу правової глобалізації, розробки системи ноосферного права і методів МП-прогнозування, - заснований на наукових уявленнях про природну єдність і безперервність простору цивілізаційно-правових подій. Своєю чергою, це дає підставу застосувати в юридико-ноосферних дослідженнях наукові методи теорії подібності, загальної топології і теорії ігор та ін., відповідно до математичних понять про «цілісність» i «нерозривність» досліджуваного глобального об'єкта. Здійснення досліджень на платформі юридичної ноосферології з використанням, топологічної інформаційно-правової Моделі ноосфери, що розроблена авторами, дозволяє вивчати виникнення i розвиток цілісного юридико-ноосферного природного феномена в єдиному просторовому континуумі в реальному часі в науковому експерименті. Такі можливості особливо важливі для пізнання законів сталого розвитку світової цивілізації в їх екологічному та правовому додатку і глобальному прояві - тобто в телеологічно обгрунтованої діяльності 3 МП-прогнозування. Це вказує на найважливішу роль юридичної ноосферології як наукової і навчальної дисципліни, яку вона здатна грати, - причому, не тільки в розробці системи ноосферного права, в розвитку всієї системи юридичних і геополітичних наук, а й розвитку різних напрямків досліджень в глобалістиці.

\section{Список використаних джерел:}

1. Рулан Норбер. Юридическая антропология : учебник для вузов. Москва : Изд-во НОРМА. 1999. 310 с.

2. Ковлер А. И. Антропология права : учебник для вузов. Москва : Изд-во HOPMA. 2002. 467 c.

3. Скоробогатов А. В., Скоробогатова А. И., Краснов А. В. Очерки по юридической антропологии. Казань : Изд-во «Познание» Казанского инновационного университета, 2019. 168 с.

4. Психолого-педагогическая антропология: Учебно-методический комплекс / авт.-сост.: К. Г. Языков, И. Л. Шелехов, Т. А. Булатова; ФГБОУ ВПО «ТГПУ». Томск : Изд-во Томского государственного педагогического университета, 2013. 308 с. 
5. Карбонье Жан. Юридическая социология : пер. с фр. / пер. и вступ. ст. В. А. Туманова. Москва : Прогресс, 1980. 352 с.

6. Дубовицкий В. Н. Основные концепции правопонимания и социология права. Право и демократия : сб. науч. тр. Минск : БГУ, 2009. Вып. 20. С. 59-74.

7. Дубовицкий В. Н. Социология права: предмет, методология и методы. Минск : Право и экономика, 2010. 174 с.

8. Бирюков С. В. О научном статусе и предмете социологии права. Вестник Омского университета. Серия «Право». 2015. № 2 (43). С. 116-122.

9. Саидов А. Х. Социология права: каков её научный статус? URL: http:/ / ecsocman.hse.ru/data/600/626/1219/saidov.pdf

10. Вернадский В. И. Научная мысль как планетное явление. Москва: Наука, 1991. 271 c.

11. Вернадский В. И. Несколько слов о ноосфере. Успехи современной биологии. 1944. № 18. Вып. 2. С. 113-120.

12. Вернадский В. И. Биосфера и ноосфера. Москва : «Наука», 1989. 261 с.

13. Международное публичное право : учебник / под ред. К. А. Бекяшева. Москва : «Проспект», 1999. 640 с.

14. Баймуратов М. А. Международное публичное право : учебник. Харьков: ООО «Одиссей», 2007. 704 с.

15. Бержель Ж.-Л. Общая теория права / под общ. ред. В. И. Даниленко / пер. с фр. Москва : Издательский дом NOTA BENE. 2000. 576 с.

16. Ивакин А. А. Предпосылки и предтечи учения о ноосфере. Актуальні проблеми філософії та соизілогї. 2016. Вип. 10. С. 58-61.

17. Ивакин А. А., Ожерельев В. П. Научно-философское толкование мифопоэтического образа дерева жизни. Актуальні проблеми фрілософіï та соціілогіï. 2017. №17. С. 32-36.

18. Баймуратов М. А., Ожерельєв В. П. Міжнародне публічне право i ноосфера: на шляху до створення єдиної аналітичної моделі. Публічне право. 2019. №1 (33). С. 120-130.

19. Баймуратов М. А., Ожерельєв В. П. Роль топологічної двоконтурної моделі ноосфери в дослідженні процесів правової глобалізації. Наукові записки Iнституту законодавства Верховної Ради Украйни. 2020. № 1. С. 8-18. URL: https:/ / instzak.com/index.php/journal/article/view/1770/1651

20. Баймуратов М. А., Ожерельев В. П. Топологічна інформаційно-правова структура ноосфери - концептуальна основа ноосферного права. Наукові записки Iнституту законодавства Верховної Ради України. 2020. № 4 . URL: https:/ / instzak.com/index.php/ journal/article/view/1770/1655

21. Боруленков Ю. П. Объект и предмет юридического познания. Закон и право. 2015. № 7. С. 22-28. URL: http://naukarus.com/obekt-i-predmetyuridicheskogo-poznaniya

22. Боруленков Ю. П. Теория юридического познания как фундаментальная наука. Вестник Московского университета МВД России. 2015. № 11. C. 10-15. URL: https://cyberleninka.ru/article/n/teoriya-yuridicheskogopoznaniya-kak-fundamentalnaya-nauka/viewer

23. Бородин Е. А. Философские проблемы становления ноосферного права: инвайронментальный дискурс «живого права» : дис. ... канд. философ. наук. Иваново, 2015. 167 с. URL: http:/ / www.ivanovo.ac.ru/upload/medialibrary 
24. Веников В. А. Теория подобия и моделирования : учеб. пособ. для вузов. Москва : Высшая школа, 1976. 479 с.

25. Фоменко А. Т. Наглядная геометрия и топология. Математические образы в реальном мире. 2-е изд. Москва : Изд-во. Моск. ун-та, Изд-во. «ЧеРо», 1988. 416 c.

26. Франсис Дж. Книжка с картинками по топологии / пер. с англ. Москва : Мир, 1991. 240 с.

27. Смирнов С. Г. Прогулки по замкнутым поверхностям. Серия: «Библиотека «Математическое просвещение». Вып. 27. Москва : МЦНМО, 2003. $28 \mathrm{c}$.

28. Заякина Р. А. Роль топологии в исследовании социальных объектов: вчера, сегодня, завтра. Идеи и Идеалы. Т. 2. Социальная фрилософия и практика. Новосибирск : Новосиб. гос. техн. ун-т. 2017. № 3(33). С. 41-52.

29. Заякина Р. А., Ромм Марк. Сетевой подход: между топологиями пространства и формы. Социологическое обозрение. 2017. Т. 16. № 2. С. 163-179.

30. Кравчук В. М. Просторовий поворот у праві: філософсько-правове розуміння. Актуальні проблеми правознавства. 2017. Вип. 3 (11). С. $20-24$.

31. Пристенский В. Н. Топология права как аспект философии человека. Известия Российского государственного педагогического университета имени А.И. Гериена. 2009. № 87. С. 60-70.

32. Василенко В. Н., Иманов Г. М. Ноосферная футурология. СанктПетербург : Изд. ООО «Лема», 2010. 866 с. URL: http://noocivil.esrae.ru/pdf/ 2012/4/925.pdf

33. Мезенцев Ю. Л. Религия и ноосферное мировоззрение. Культура народов Причерноморья. 2012. C. http://dspace.nbuv.gov.ua/handle/123456789/55852

34. Ноосферна парадигма в публічному управлінні: теорія, історія, сучасність : матер/ наук.-практ. конф., 15 березня 2017 р. Харків : Вид-во ХарРІ НАДУ, 2017. 208 c. URL: http:/ /www.kbuapa.kharkov.ua/e-book/conf/2017-4/2017_01.pdf

35. Нефёдов Б. И. Катехизис аспиранта кафедры международного права : учебное пособие / отв. ред. А. Н. Вылегжанин. Москва : МГИМО- Университет, 2018. 462 c.

36. Декларация Конференции Организации Объединенных Наций по проблемам окружающей человека среды (Стокгольмская декларация) 1972 года и Рио-де-Жанейрская декларация по окружающей среде и развитию 1992 года. URL: https://legal.un.org/avl/pdf/ha/dunche/dunche_r.pdf

37. Конференция Организации Объединенных Наций по устойчивому развитию "Рио+20"19 https://apps.who.int/gb/ebwha/pdf_files/EB130/B130_36-ru.pdf

38. Перетворення нашого світу: Порядок денний в галузі сталого розвитку на період до 2030 року : Резолюція, прийнята Генеральною Асамблеєю ООН 25 вересня 2015 року (A/70/L.1). URL: http://sdg.org.ua/ua/resources-2/344-20302015

39. Мезенцев Ю. Л. Ноосферное мировоззрение - стратегия выживания современной цивилизации. Учёные записки Таврического национального университета им. В.В. Вернадского. Серия «Филология. Социальные коммуникаиии». 2011. Том 24 (63). №3. С. 309-316. 
40. Пантелеева Г. Г. Ноосферно-антропологические идеи как условие целостности человека. Ученые записки Таврического национального университета им. В. И. Вернадского. Серия «Философия. Культурология. Соииология». 2011. Том 24 (63). №2. C. 66-75.

41. Ноосферный проект социоприродной эволюции: поиск алгоритмов устойчивости : коллективная монография / отв. ред. Д.Е. Муза. Донецк : ДонНТУ, Технопарк ДонНТУ УНИТЕХ, 2014. 288 с.

42. Жарков В. О. Концептуальні засади формування сталого розвитку в Україні. Наукові записки Інституту законодавства Верховної Ради України. 2020. №1. C. 137-145.

43. Урсул А. Д., Урсул Т. А. Цели перехода к устойчивому развитию человеческой цивилизации. Знание. Понимание. Умение. Гуманитарные науки: теория и методология. 2016. № 2. С. 65-72.

44. Урсул А. Д. На пути к ноосферной цивилизации: взаимосвязь цивилизационных и ноосферных исследований. Политика и общество. 2014. №12 (120). С. 1501-1520.

45. Магидович И. П., Магидович В. И. Очерки по истории географических открытий. В 5-ти т. Т. 2. Великие географические открытия (конеи XV - средина XVII в.). Москва : Просвещение, 1983. 399 с.

46. История Средних веков: В 2 т. Т. 1: Раннее Новое время: учебник / под ред. С. П. Карпова. Москва : Изд-во Моск. ун-та; Изд-во «Печатные Традиции», 2008. 681 c.

47. История Средних веков : в 2 т. Т. 2: Раннее Новое время: учебник / под ред. С. П. Карпова. Москва : Изд-во Моск. ун-та; Изд-во «Печатные Традиции», 2008. 432 c.

48. Испано-португальские договоры о разделе колониальных владений в 15-18 веках. Национальная политическая энциклопедия. URL: http:/ / politike.ru/termin/ispano-portugalskie-dogovory.html

49. Горбань А. В. Проблемы и перспективы глобального и регионального стабилизирующего развития: социально-философский анализ. URL: http://dspace.nbuv.gov.ua/bitstream/handle/ 123456789/90962/28Gorban.pdf?sequence=1

50. Елацков А. Б. Геополитическое поле. Секция: «История и теория геополитики». Актуальные вопросы общественных наук: социология, политология, философия, история : сб. ст. по материалам LIX-LX междунар. науч.-практ. конф. Новосибирск : Изд. АНС «СибАК», 2016. № 3-4 (55). С. 76-80.

51. География мира. В 3 т. Том 1. Политическая география и геополитика : учебник и практикум для вузов / Н. В. Каледин и др.; под редакцией Н. В. Каледина, Н. М. Михеевой. 2-е изд., перераб. и доп. Москва : Издательство Юрайт, 2019. 388 с.

\section{References:}

1. Rulan, Norber. (1999). Juridicheskaja antropologija: uchebnik dlja vuzov [Legal anthropology: textbook for universities]. Moscow: Izd-vo NORMA. [in Russian].

2. Kovler, A. I. (2002). Antropologija prava: uchebnik dlja vuzov [Anthropology of law: textbook for universities]. Moscow: Izd-vo NORMA. [in Russian]. 
3. Skorobogatov, A. V., Skorobogatova, A. I., Krasnov, A. V. (2019). Ocherki po juridicheskoj antropologii [Essays on Legal Anthropology]. Kazan: Izd-vo «Poznanie» Kazanskogo innovacionnogo universiteta. [in Russian].

4. Jazykov, K. G., Shelehov, I. L., Bulatova, T. A. (2013). Psihologo-pedagogicheskaja antropologija: uchebno-metodicheskij kompleks [Psychological and pedagogical anthropology: educational and methodological complex]. Tomsk: Izd-vo Tomskogo gosudarstvennogo pedagogicheskogo universiteta. [in Russian].

5. Karbon'e, Zhan. (1980). Juridicheskaja sociologija [Legal Sociology]. Moscow: Progress. [in Russian].

6. Dubovickij, V. N. (2009). Osnovnye koncepcii pravoponimanija i sociologija prava [Basic concepts of legal thinking and sociology of law]. Pravo $i$ demokratija [Law and democracy], iss. 20, 59-74. [in Russian].

7. Dubovickij, V. N. (2010). Sociologija prava: predmet, metodologija i metody [Sociology of law: subject, methodology and methods]. Minsk: Pravo i jekonomika. [in Russian].

8. Birjukov, S. V. (2015). O nauchnom statuse i predmete sociologii prava [About the scientific status and the subject of sociology of law]. Vestnik Omskogo universiteta. Serija «Pravo» [Omsk University Bulletin. Series "Law"], no. 2 (43), 116-122. [in Russian].

9. Saidov, A. H. Sociologija prava: kakov ejo nauchnyj status? [Sociology of law: what is its scientific status?]. URL:

http://ecsocman.hse.ru/data/600/626/1219/saidov.pdf [in Russian].

10. Vernadskij, V. I. (1991). Nauchnaja mysl' kak planetnoe javlenie [Scientific thought as a planetary phenomenon]. Moscow: Nauka. [in Russian].

11. Vernadskij, V. I. (1944). Neskol'ko slov o noosfere [A few words about the noosphere]. Uspehi sovremennoj biologii [Advances in modern biology], no. 18, iss. 2, 113-120. [in Russian].

12. Vernadskij, V. I. (1989). Biosfera i noosfera [Biosphere and noosphere]. Moscow: «Nauka»,. [in Russian].

13. Bekjashev, K. A. (ed.) (1999). Mezhdunarodnoe publichnoe pravo: uchebnik [Public International Law: Textbook]. Moscow: «Prospekt». [in Russian].

14. Bajmuratov, M. A. (2007). Mezhdunarodnoe publichnoe pravo: uchebnik [Public International Law: Textbook]. Kharkiv: OOO «Odissej». [in Russian].

15. Berzhel', Zh.-L. (2000). Obshhaja teorija prava [General theory of law]. Moscow: Izdatel'skij dom NOTA BENE. [in Russian].

16. Ivakin, A. A. (2016). Predposylki i predtechi uchenija o noosfere [Preconditions and forerunners of the noosphere]. Aktualni problemy filosofii ta sotsiolohii [Current issues of philosophy and sociology], iss. 10, 58-61. [in Russian].

17. Ivakin, A. A., Ozherel'ev, V. P. (2017). Nauchno-filosofskoe tolkovanie mifopojeticheskogo obraza dereva zhizni [Scientific and philosophical interpretation of the mythopoetic way of the tree of life]. Aktualni problemy filosofii ta sotsiolohii [Current issues of philosophy and sociology], no. 17, 32-36. [in Russian].

18. Baimuratov, M. A., Ozhereliev, V. P. (2019). Mizhnarodne publichne pravo i noosfera: na shliakhu do stvorennia yedynoi analitychnoi modeli [International public law and the noosphere: on the way to creating a unified analytical model]. Publichne pravo [Public law], no. №1 (33), 120-130. [in Ukrainian].

19. Baimuratov, M. A., Ozhereliev, V. P. (2020). Rol topolohichnoi dvokonturnoi modeli noosfery $\mathrm{v}$ doslidzhenni protsesiv pravovoi hlobalizatsii [The role of the 
topological two-loop model of the noosphere in the study of the processes of legal globalization]. Naukovi zapysky Instytutu zakonodavstva Verkhovnoi Rady Ukrainy [Scientific notes of the Institute of Legislation of the Verkhovna Rada of Ukraine], no. 1, 8-18. URL: https://instzak.com/index.php/journal/article/view/1770/1651 [in Ukrainian].

20. Baimuratov, M. A., Ozherelev, V. P. (2020). Topolohichna informatsiino-pravova struktura noosfery - kontseptualna osnova noosfernoho prava [The topological information and legal structure of the noosphere is the conceptual basis of noosphere law]. Naukovi zapysky Instytutu zakonodavstva Verkhovnoi Rady Ukrainy [Scientific notes of the Institute of Legislation of the Verkhovna Rada of Ukraine], no. 4. URL: https://instzak.com/index.php/journal/article/view/1770/16551651 [in Ukrainian].

21. Borulenkov, Ju. P. (2015). Obekt i predmet juridicheskogo poznanija [Object and subject of legal knowledge]. Zakon i pravo [Laws and regulations], no. 7, 22-28. URL: http:/ / naukarus.com/obekt-i-predmet-yuridicheskogo-poznaniya [in Russian].

22. Borulenkov, Ju. P. (2015). Teorija juridicheskogo poznanija kak fundamental'naja nauka [The theory of legal knowledge as a fundamental science]. Vestnik Moskovskogo universiteta MVD Rossii [Bulletin of the Moscow University of the Ministry of Internal Affairs of Russia], no. 11, 10-15. URL: https:/ / cyberleninka.ru/article/n/teoriya-yuridicheskogo-poznaniya-kakfundamentalnaya-nauka/viewer [in Russian].

23. Borodin, E. A. (2015). Filosofskie problemy stanovlenija noosfernogo prava: invajronmental' nyj diskurs «zhivogo prava»: discertacija kandidata filosofskih nauk [Philosophical problems of the formation of noospheric law: environmental discourse of "living law": dissertation of the candidate of philosophical sciences]. Ivanovo. URL:

http://www.ivanovo.ac.ru/upload/medialibrary/78f/BorodinDisser.pdf [in Russian].

24. Venikov, V. A. (1976). Teorija podobija i modelirovanija: uchebnoe posobie [Similarity theory and modeling: a tutorial]. Moscow: Vysshaja shkola. [in Russian].

25. Fomenko, A. T. (1988). Nagljadnaja geometrija i topologija. Matematicheskie obrazy $v$ real'nom mire [Intuitive geometry and topology. Mathematical images in the real world]. 2-e izd. Moscow: Izd-vo. Mosk. un-ta, Izd-vo. «CheRo». [in Russian].

26. Fransis, Dzh. (1991). Knizhka s kartinkami po topologii [Topology picture book]. Moscow: Mir. [in Russian].

27. Smirnov, S. G. (2003). Progulki po zamknutym poverhnostjam [Walking on enclosed surfaces]. Serija: «Biblioteka «Matematicheskoe prosveshhenie» [Series: "Library" Mathematical Education"], iss. 27. Moscow: MCNMO. [in Russian].

28. Zajakina, R. A. (2017). Rol' topologii v issledovanii social'nyh ob\#ektov: vchera, segodnja, zavtra. Idei i Idealy [The role of topology in the study of social objects: yesterday, today, tomorrow. Ideas and Ideals]. Vol. 2. Social'naja filosofija $i$ praktika [Vol. 2. Social philosophy and practice], no. 3(33), 41-52. [in Russian].

29. Zajakina, R. A., Romm, Mark. (2017). Setevoj podhod: mezhdu topologijami prostranstva i formy [Networked Approach: Between Space and Shape Topologies]. Sociologicheskoe obozrenie [Sociological Review], vol. 16, no. 2, 163-179. [in Russian].

30. Kravchuk, V. M. (2017). Prostorovyi povorot u pravi: filosofsko-pravove rozuminnia [Spatial turn in law: philosophical and legal understanding]. Aktualni 
problemy pravoznavstva [Actual problems of jurisprudence], iss. 3 (11), 20-24. [in Ukrainian].

31. Pristenskij, V. N. (2009). Topologija prava kak aspekt filosofii cheloveka [Topology rights as an aspect of human philosophy]. Izvestija Rossijskogo gosudarstvennogo pedagogicheskogo universiteta imeni A.I. Gercena [Bulletin of the Russian State Pedagogical University named after A.I. Herzen], no. 87, 60-70. [in Russian].

32. Vasilenko, V. N., Imanov, G. M. (2010). Noosfernaja futurologija [Noosphere futurology]. St. Petersburg: Izd. OOO «Lema». URL: http://noocivil.esrae.ru/pdf/ 2012/4/925.pdf [in Russian].

33. Mezencev, Ju. L. (2012). Religija i noosfernoe mirovozzrenie [Religion and noospheric worldview]. Kul'tura narodov Prichernomor'ja [Culture of the peoples of the Black Sea region], 94-96. URL:

http://dspace.nbuv.gov.ua/handle/123456789/55852 [in Russian].

34. Noosferna paradyhma v publichnomu upravlinni: teoriia, istoriia, suchasnist [Noosphere paradigm in public administration: theory, history, modernity] (2017). Kharkiv: Vyd-vo KharRI NADU. URL: http:/ / www.kbuapa.kharkov.ua/ebook/conf/2017-4/2017_01.pdf [in Ukrainian].

35. Nefjodov, B. I. (2018). Katehizis aspiranta kafedry mezhdunarodnogo prava: uchebnoe posobie [Catechism of a Postgraduate Student of the Department of International Law: Study Guide]. Moscow: MGIMO- Universitet. [in Russian].

36. Deklaracija Konferencii Organizacii Ob\#edinennyh Nacij po problemam okruzhajushhej cheloveka sredy (Stokgol'mskaja deklaracija) 1972 goda i Rio-de-Zhanejrskaja deklaracija po okruzhajushhej srede i razvitiju 1992 goda [Declaration of the United Nations Conference on the Human Environment (Stockholm Declaration) 1972 and Rio Declaration on Environment and Development 1992]. URL: https://legal.un.org/avl/pdf/ha/dunche/dunche_r.pdf [in Russian].

37. Konferencija Organizacii Obedinennyh Nacij po ustojchivomu razvitiju "Rio+20"19 janvarja 2012 [United Nations Conference on Sustainable Development "Rio + 20" January 19, 2012]. URL: https://apps.who.int/gb/ebwha/pdf_files/EB130/B130_36ru.pdf [in Russian].

38. Rezoliutsiia Heneralnoi Asamblei OON pro Peretvorennia nashoho svitu: Poriadok dennyi v haluzi staloho rozvytku na period do 2030 roku (pryiniata 25 veresnia 2015 roku) [UN General Assembly Resolution on the Transformation of Our World: The 2030 Agenda for Sustainable Development (adopted on 25 September 2015)]. URL: http://sdg.org.ua/ua/resources-2/344-2030-2015 [in Ukrainian].

39. Mezencev, Ju. L. (2011). Noosfernoe mirovozzrenie - strategija vyzhivanija sovremennoj civilizacii [Noospheric worldview - a strategy for the survival of modern civilization]. Uchjonye zapiski Tavricheskogo nacional'nogo universiteta im. V.V. Vernadskogo. Serija «Filologija. Social'nye kommunikacii» [Scientific notes of the Tavrichesky National University named after V.V. Vernadsky. Series "Philology. Social communications"], vol. 24 (63), no. 3, 309-316. [in Russian].

40. Panteleeva, G. G. (2011). Noosferno-antropologicheskie idei kak uslovie celostnosti cheloveka [Noospheric-anthropological ideas as a condition of human integrity]. Uchenye zapiski Tavricheskogo nacional'nogo universiteta im. V. I. Vernadskogo. Serija «Filosofija. Kul' turologija. Sociologija» [Scientific notes of the Tavrichesky National University named after V.I. Vernadsky. Series "Philosophy. Culturology. 
Sociology"], vol. 24 (63), no. 2, 66-75. [in Russian].

41. Muza, D. E. (ed.) (2014). Noosfernyj proekt socioprirodnoj jevoljucii: poisk algoritmov ustojchivosti: kollektivnaja monografija. Donetsk: DonNTU, Tehnopark DonNTU UNITEH. [in Russian].

42. Zharkov, V. O. (2020). Kontseptualni zasady formuvannia staloho rozvytku v Ukraini [Conceptual bases of formation of sustainable development in Ukraine]. Naukovi zapysky Instytutu zakonodavstva Verkhovnoi Rady Ukrainy [Scientific notes of the Institute of Legislation of the Verkhovna Rada of Ukraine], no. 1, 137-145. [in Ukrainian].

43. Ursul, A. D., Ursul, T. A. (2016). Celi perehoda k ustojchivomu razvitiju chelovecheskoj civilizacii. Znanie. Ponimanie. Umenie [Goals of the transition to sustainable development of human civilization. Knowledge. Understanding. Skill]. Gumanitarnye nauki: teorija i metodologija [Humanities: theory and methodology], no. 2, 65-72. [in Russian].

44. Ursul, A. D. (2014). Na puti k noosfernoj civilizacii: vzaimosvjaz' civilizacionnyh i noosfernyh issledovanij [Towards a noospheric civilization: the relationship between civilizational and noospheric research]. Politika i obshhestvo [Politics and society], no. 12 (120), 1501-1520. [in Russian].

45. Magidovich, I. P., Magidovich, V. I. (1983). Ocherki po istorii geograficheskih otkrytij. V 5-ti t. [Essays on the history of geographical discoveries. In 5 volumes.] T. 2. Velikie geograficheskie otkrytija (konec XV-sredina XVII v.) [Vol. 2. The great geographical discoveries (the end XV - The middle of the XVII century.)]. Moscow: Prosveshhenie. [in Russian].

46. Karpov, S. P. (ed.) (2008). Istorija Srednih vekov: v 2 t. [History of the Middle Ages: in 2 volumes.]. T. 1: Rannee Novoe vremja [Vol. 1: Early Modern Times].

Moscow: Izd-vo Mosk. un-ta; Izd-vo «Pechatnye Tradicii». [in Russian].

47. Karpov, S. P. (ed.) (2008). Istorija Srednih vekov: v 2 t. [History of the Middle Ages: in 2 volumes.]. T. 2: Rannee Novoe vremja [Vol. 2: Early Modern Times]. Moscow: Izd-vo Mosk. un-ta; Izd-vo «Pechatnye Tradicii». [in Russian].

48. Ispano-portugal'skie dogovory o razdele kolonial'nyh vladenij v 15-18 vekah [Spanish-Portuguese treaties on the division of colonial possessions in the 15-18 centuries]. Nacional' naja politicheskaja jenciklopedija [National Political Encyclopedia]. URL: http:/ / politike.ru/termin/ispano-portugalskie-dogovory.html [in Russian].

49. Gorban', A. V. Problemy i perspektioy global'nogo i regional'nogo stabilizirujushhego razvitija: social'no-filosofskij analiz [Problems and Prospects of Global and Regional Stabilizing Development: Socio-Philosophical Analysi]. URL: http://dspace.nbuv.gov.ua/bitstream/handle/ 123456789/90962/28Gorban.pdf?sequence=1 [in Russian].

50. Elackov, A. B. (2016). Geopoliticheskoe pole [Geopolitical field]. Aktual'nye voprosy obshhestvennyh nauk: sociologija, politologija, filosofija, istorija [Actual issues of social sciences: sociology, political science, philosophy, history], no. 3-4 (55), 76-80. [in Russian].

51. Kaledin, N. V. et al (2019). Geografija mira. V 3 t. [The geography of the world. In 3 volumes.] Tom 1. Politicheskaja geografija i geopolitika: uchebnik i praktikum dlja vuzov [Political geography and geopolitics: textbook and workshop for universities]. Moscow: Izdatel'stvo Jurajt. [in Russian]. 